\title{
MULTIPARENTALIDADE E A EFETIVIDADE DO DIREITO DA PERSONALIDADE AOS ALIMENTOS: Uma Análise a Partir da Visão do Supremo Tribunal Federal No Re 898.060
}

http://dx.doi.org/10.21527/2176-6622.2020.54.246-259

Recebido em: 9/3/2020

Modificações solicitadas em: 24/5/2020

Aceito em: 3/6/2020

Dirceu Pereira Siqueira

Coordenador e professor permanente do Programa de Doutorado e Mestrado em Direito do Centro Universitário Cesumar (UniCesumar). Pós-doutor em Direito pela Faculdade de Direito da Universidade de Coimbra (Portugal). Doutor e mestre em Direito Constitucional pela Instituição Toledo de Ensino (ITE/Bauru). Especialista Lato Sensu em Direito Civil e Processual Civil pelo Centro Universitário de Rio Preto. Pesquisador Bolsista-Modalidade Produtividade em Pesquisa para Doutor (PPD) do Instituto Cesumar de Ciência, Tecnologia e Inovação (Iceti). Professor nos cursos de Graduação em Direito da Universidade de Araraquara (Uniara), do Centro Universitário Unifafibe (Unifafibe) e do Centro Universitário da Fundação Educacional de Barretos (Unifeb). Professor convidado do Programa de Mestrado em "Gestão Estratégica de Empresas - Master Of Science in Administrative Studies (MSAS)" - University Missouri State (EUA). Editor-chefe da Revista Direitos Sociais e Políticas Públicas. Consultor jurídico. Parecerista. Advogado. http://lattes.cnpq.br/3134794995883683. https://orcid.org/0000-0001-9073-7759. dpsiqueira@uol.com.br

Henriqueta Fernanda Chaves Alencar Ferreira Lima

Mestranda em Direito pelo Centro Universitário de Maringá/PR - Unicesumar. Juíza de Direito do Tribunal de Justiça do Estado de Mato Grosso. http://lattes.cnpq.br/8180754714236361. https://orcid.org/0000-0001-7432-2895. henriqueta.lima@tjmt.jus.br

RESUMO

A Constituição Federal veio não só inaugurar uma nova ordem constitucional, mas atribuir à dignidade da pessoa humana a função de irradiar seus efeitos para todo o ordenamento jurídico, inclusive às relações privadas, até então norteadas pelo patrimonialismo. No âmbito do Direito das Famílias não foi diferente: o modelo tradicional de família, decorrente do matrimônio, cedeu espaço a novas configurações familiares, em que a multiparentalidade passou a ser uma realidade, exigindo dos julgadores interpretação para além das regras. Nessa perspectiva, o afeto passa a ser elemento essencial, de modo que a filiação socioafetiva passa a ter preponderância diante do critério meramente biológico, admitindo-se a existência concomitante do pai/mãe sanguíneo com o afetivo, exsurgindo o debate doutrinário e jurisprudencial quanto aos efeitos patrimoniais dessa relação. Nesse viés, o presente estudo dedicar-se-á a analisar, especificamente, tomando como base os princípios da dignidade da pessoa humana, da solidariedade, da afetividade e da paternidade responsável, o instituto dos alimentos, aqui considerando como direito da personalidade, apontando as controvérsias, as implicações práticas e a efetividade, com o fito de compreender como os alimentos podem ser resguardados nessa nova formatação de familiar sem se incorrer em insegurança jurídica e enriquecimento indevido. Para tanto, utilizar-se-á do método dedutivo, de pesquisa teórica e da metodologia de análise de decisões, especialmente do julgado emblemático do Supremo Tribunal Federal (STF) no Recurso Extraordinário (RExt) 898.060 por ter sedimentado o debate quanto à pluriparentalidade, sem, contudo, ter adentrado à análise dos limites, alcance e, sobretudo, os impactos jurídicos noutros institutos.

Palavras-chave: Multiparentalidade. Alimentos. Direitos da personalidade. STF e RExt 898.060.

MULTIPARENTALITY AND THE EFFECTIVENESS OF THE RIGHT OF PERSONALITY TO FOOD: AN ANALYSIS FROM THE VIEW OF THE SUPREME FEDERAL COURT IN RE 898.060

\section{ABSTRACT}

The Federal Constitution came not only to inaugurate a new order constitutional, but to attribute to the dignity of the human person the function of radiating its effects to the entire legal system, including to the private relations, until then guided by patrimonialism. In the scope of Family Law, it was no different: the traditional family model, resulting from marriage, gave way to new family configurations, in which multiparenting became a reality, requiring judges to interpret beyond the rules. Within this perspective, affection becomes an essential element, so that the socio-affective affiliation starts to have preponderance to the purely biological criterion, admitting the concomitant existence of the bloody father / mother with the affective, resulting in the doctrinal and jurisprudential debate regarding the equity effects of this relationship. In this bias, this study will be dedicated to analyzing, specifically, based on the principles of human dignity, solidarity, affection and responsible parenting, the food institute, here considering as a right of the personality, pointing out the controversies, the practical implications and effectiveness, in order to understand how food can be protected in this new formatting of family members without incurring legal uncertainty and undue enrichment. For this purpose, the deductive method, theoretical research and decision analysis methodology will be used, especially the emblematic judgment of the Supreme Federal Court (STF) in the Extraordinary Appeal (RExt) 898.060 for having settled the debate on pluriparenting, without, however, having entered into the analysis of the limits, scope and, above all, the legal impacts in other institutes.

Keywords: Multiparenting. Foods. Personality rights. STF and RExt 898.060

\section{SUMÁRIO}

1 Introdução. 2 Direito das Famílias Contemporâneo, o Princípio da Afetividade e os Alimentos. 2.1 Princípio da Dignidade da Pessoa Humana e Família. 2.2 Princípio da Solidariedade Familiar. 2.3 Princípio da Afetividade. 2.4 Alimentos Como Direito da Personalidade. 3 Multiparentalidade e Alimentos na Visão do STF no Recurso Extraordinário. 3.1 Os Alimentos na Multiparentalidade e STF. 4 Considerações Finais. 5 Referências. 


\section{INTRODUÇÃO}

A Constituição Federal de 1988 erigiu a dignidade da pessoa humana à condição de fundamento da República Federativa do Brasil e, ante sua força normativa, irradia seus efeitos a todo ordenamento jurídico, incorporando-lhe carga axiológica.

Nessa perspectiva, a definição de norma como regra passa a ser insuficiente, eis que aspecto valorativo passa a integrar e a afetar as relações horizontais e verticais, o que, inclusive, impactou nas relações familiares, filiatórias, e, logo, no Direito Civil.

Com o movimento chamado por alguns como "Constitucionalização do Direito Privado", por outros como "Publicização do Direito Civil", relações jurídicas dantes norteadas pelo exercício da autonomia da vontade cedem espaço para a "função social" dos institutos (dos contratos, da propriedade, da família), de modo que as entidades familiares deixam de ser sinônimo de "família matrimonial" para incluir uma pluralidade de configurações em que o afeto passa a ser elemento essencial e a merecer a tutela própria do Direito das Famílias.

O Direito Civil contemporâneo, assim, abandonou o modelo tradicional de enxergar tais relações calcadas no patrimonialismo e tão somente no matrimônio, passando a flexibilizar alguns institutos, tais como o da filiação, inserindo princípios como a afetividade, a solidariedade e a responsabilidade parental.

Assim, considerando o afeto como elemento essencial e a pluralidade de entidades familiares, o presente artigo propõe-se a analisar o fenômeno da multiparentalidade no qual o arranjo familiar é caracterizado pela presença concomitante da paternidade biológica e a afetividade, e seus efeitos práticos nos alimentos, aqui abordados como direito da personalidade.

Ora, o instituto dos alimentos, numa acepção ampla em que se considera verdadeiro instrumento à concretização de direitos mais elementares, como à saúde, à moradia, à educação, ao lazer, enfim, à vida digna, tem seu espectro de legitimados ativo e passivo ampliado, inclusive podendo-se admitir a concomitância de prestação alimentícia em relação pluriparental.

Nesse sentido, pretende-se investigar as implicações tanto no direito material como processual, do reconhecimento da multiparentalidade nos alimentos, analisando de modo crítico e com o olhar voltado à vedação do enriquecimento indevido e ao melhor interesse do petiz, o que é de grande relevância ante a ausência de debate aprofundado quanto ao tema, havendo, decerto, a defesa da ampliação do espectro da entidade familiar sem a preocupação com os impactos materiais.

Buscar-se-á responder à seguinte indagação: Partindo-se da premissa de que é possível se admitir o direito da personalidade aos alimentos no contexto da multiparentalidade, indaga-se a efetividade de tal direito e os impactos à segurança jurídica?

De início, analisando o Direito das Famílias na contemporaneidade, em que a constitucionalização das relações privadas e a influência dos princípios, como o da dignidade da pessoa humana, da solidariedade, da afetividade, da responsabilidade parental e do melhor interesse, passa a ser notória, estudar-se-á o instituto dos alimentos, desde da sua conceituação, considerando-os como direitos da personalidade, até a (im)possibilidade de sua aplicação quando há multiparentalidade.

Em seguida, adentrar-se-á nas especificidades da pluriparentalidade com ênfase nas implicações práticas nos alimentos, apontando para as divergências doutrinárias e a efetividade do instituto, detalhando a posição do Supremo Tribunal Federal no Recurso Extraordinário no 898.060.

Para tanto, partir-se-á do método dedutivo e buscar-se-á, do julgamento da Suprema Corte, no mencionado julgado, utilizando-se da metodologia de pesquisa conhecida por "análise de decisões", demonstrar a viabilidade constitucional de a pluralidade parental ensejar o direito/dever de prestar alimentos e o impacto à efetividade de tal direito da personalidade, uma vez que em tal julgado não se estabeleceu limites, tampouco se analisou os consectários jurídicos para além do reconhecimento de filiação simultânea.

Assinale-se, por oportuno, que a metodologia de análise de decisões consiste na organização das informações relativas ao tema, a partir de revisão doutrinária e jurisprudencial quanto ao objeto a ser estudado; após, verifica-se a coerência com tal pretensão; em seguida, investiga-se os argumentos tecidos na decisão 
eleita e a viabilidade do seu uso para a pesquisa. Ou seja: de pronto, procede-se à pesquisa exploratória com o fito de se familiarizar com o objeto de estudo e, após, faz-se o recorte teórico dentro da decisão judicial escoIhida, selecionando os aspectos a serem problematizados, com o aprofundamento da abordagem.

\section{DIREITO DAS FAMÍLIAS CONTEMPORÂNEO, O PRINCÍPIO DA AFETIVIDADE E OS ALIMENTOS}

O Direito Civil contemporâneo abandonou o modelo patrimonialista e extremamente formal, fruto da influência do Código Napoleônico, para adotar um método mais flexível, fundado em cláusulas gerais inspiradas em valores e princípios constitucionais, de modo que a doutrina, a exemplo de autores como Paulo Lobo, Maria Berenice Dias, Rolf Madaleno, passou a falar em "Direito Civil Constitucional".

De fato, observa-se a força normativa da Constituição Federal em todo o ordenamento jurídico, como bem assinalado por Konrad Hesse, como se depreende do fato de os valores da dignidade humana, igualdade e solidariedade serem estruturantes do Direito civil-constitucional e, sobretudo, das relações jurídicas familiares nas quais o afeto, o respeito, o pluralismo e a responsabilidade parental são notórios, passando-se a falar em personalização do Direito Privado, como assinalado por Luiz Edson Fachin (2001, p. 1).

Nessa senda, partindo da premissa pós-positivista de que o conceito de norma jurídica não mais se resume à regra, mas inclui o princípio nesse contexto, dando carga axiológica, mister, ao cuidar do instituto dos alimentos no Direito das Famílias, estudar, de modo não exaustivo, o que seria muita pretensão, alguns princípios aplicáveis aos alimentos nas relações parentais.

\subsection{Princípio da Dignidade da Pessoa Humana e Família}

A Declaração Universal de Direitos Humanos de 1948, em seu artigo XXV, assinala que:

Todo ser humano tem direito a um padrão de vida capaz de assegurar a si e à sua família saúde e bem-estar, inclusive alimentação, vestuário, habitação, cuidados médicos e os serviços sociais indispensáveis, e direito à segurança em caso de desemprego, doença, invalidez, viuvez, velhice ou outros casos de perda dos meios de subsistência fora de seu controle.

O constituinte originário, na mesma toada, erigiu a dignidade da pessoa humana, aqui sinônimo de valor fundante do ordenamento jurídico que permite que direitos fundamentais (plano interno e na relação Estado-pessoa) e da personalidade (plano interno e na relação entre particulares) sejam tutelados, como fundamento do Estado Democrático de Direito (artigo 1으, III). Nesse sentido, leciona Zulmar Fachin (2019, p. 208) que "O constituinte de 1988 erigiu a pessoa humana como valor supremo do ordenamento jurídico", o que indica predileção por concepção humanista em que o valor "dignidade" irradia seus efeitos e cria direitos e deveres.

Acerca do mencionado princípio, em trabalho magistral, Ingo Wolfgang Sarlet, após extenso estudo, inclusive fazendo retrospecto filosófico, define a dignidade da pessoa humana como

[...] a qualidade intrínseca e distintiva de cada ser humano que o faz merecedor do mesmo respeito e consideração por parte do Estado e da comunidade, implicando, neste sentido, um complexo de direitos e deveres fundamentais que assegurem a pessoa tanto contra todo e qualquer ato de cunho degradante e desumano, como venham a lhe garantir as condições existenciais mínimas para uma vida saudável, além de propiciar e promover sua participação ativa e co-responsável nos destinos da própria existência e da vida em comunhão com os demais seres humanos $(2001$, p. 60$)$.

Na mesma concepção de Gustavo Tepedino (2004a), a civilista Maria Celina Bodin de Moraes (2008), em clara vinculação do princípio da dignidade da pessoa humana com os direitos fundamentais, e, por conseguinte, com os direitos da personalidade, assinalou que:

No direito brasileiro, a previsão do inciso III do art. 10 da Constituição, ao considerar a dignidade humana como valor sobre o qual se funda a República, representa uma verdadeira cláusula geral de tutela de todos os direitos que da personalidade irradiam. 
Assim, em nosso ordenamento, o princípio da dignidade da pessoa humana atua como uma cláusula geral de tutela e promoção da personalidade em suas mais diversas manifestações que, portanto, não pode ser limitada em sua aplicação pelo legislador ordinário (MORAES, 2008, p. 5).

Vê-se, pois, que os direitos fundamentais e os direitos da personalidade revelam-se como integrantes da dignidade da pessoa humana e por ter a Constituição Federal erigido tal princípio como fundamento da República, atribuindo efeito irradiante, aqueles direitos passam a ocupar posição de centralidade do ordenamento civil e resguardar uma tutela quase que absoluta.

No Direitos das Famílias, aqui já ultrapassando a antiga celeuma quanto à existência da pluralidade de entidade familiar, a importância singular de que se reveste este princípio é apontada por Paulo Lôbo ao defender que o artigo 226, caput, Constituição Federal, cria verdadeira "cláusula geral de abertura", e o artigo 227 elenca direitos da criança e do adolescente - tais como vida, saúde, educação, profissionalização, lazer - e o papel do Estado, da sociedade e da família em seu resguardo (2010, p. 61), garantindo o famoso "mínimo existencial".

\subsection{Princípio da Solidariedade Familiar}

Disposto no inciso I, artigo 3ำ, da Constituição Federal, o princípio da solidariedade é produto da superação do individualismo jurídico e impõe o dever de assistência e de promoção de direitos básicos à pessoa dotada de dignidade.

No âmbito das relações familiares, tem-se como exemplo clássico de aplicação desse princípio o dever de cuidado, seja material, seja moral, entre parentes e cônjuges/companheiros, como bem assinala Paulo Lobo (2010, p. 64), destacando que a solidariedade se faz presente quando o afeto, o respeito mútuo, o cuidado e a cooperação norteiam a relação, surgindo de modo espontâneo, de modo que "[...] o direito os traz a seu plano, convertendo-os de fatos psicológicos ou anímicos em categorias jurídicas, para iluminar a regulação das condutas" (2010, p. 5).

Ora, a solidariedade familiar deve ser concebida em sentido amplo, tendo caráter afetivo, social, moral, patrimonial, espiritual e sexual, gerando direitos e deveres, encontrando no Código Civil atual sua normatização no plano infraconstitucional, como o reconhecimento jurisprudencial aos alimentos decorrentes da multiparentalidade.

\subsection{Princípio da Afetividade}

No contexto de personificação do Direito Civil em que a pessoa, na condição de ser dotado de dignidade passa a ser o cerne das relações, a tutela jurídica do afeto não mais enseja maiores debates, havendo, decerto, discussões quanto à sua natureza jurídica: ora quem defenda ser valor jurídico (CARDIN et al., seguindo posição o STJ), ora os que o tratam como princípio (TARTUCE, 2011).

Mister trazer à colação importante ponderação suscitada por Flávio Tartuce (2011, p. 988) quando afirma que, entrementes o aspecto afetivo não esteja taxativamente presente na norma constitucional, a ponto de incluir o afeto no rol dos direitos fundamentais, sua presença no âmbito dos princípios do Direito de Família decorre "da valorização constante da dignidade humana e da solidariedade".

Reconhecendo a relevância do afeto à configuração da família, reconhecendo a afetividade como princípio, a juspsicanalista Giselle Câmara Groeninga leciona que:

O papel dado à subjetividade e à afetividade tem sido crescente no Direito de Família, que não mais pode excluir de suas considerações a qualidade dos vínculos existentes entre os membros de uma família, de forma que possa buscar a necessária objetividade na subjetividade inerente às relações. Cada vez mais se dá importância ao afeto nas considerações das relações familiares; aliás, um outro princípio do Direito de Família é o da afetividade (2008, p. 47-52). 
Ora, ante a relevância ao desenvolvimento do ser humano e os impactos à subjetividade, o afeto passou a ser ponderado e considerado nas relações familiares, merecendo a tutela estatal, tanto que Paulo Lôbo $(2010$, p. 71$)$ retira do texto constitucional fundamentos essenciais ao princípio da afetividade que se resumem em tratamento igualitário entre filhos independentemente da origem, inclusive a adoção (artigo 226, §60) e o direito prioritário à convivência familiar (artigo 227).

Depreende-se, assim, do mencionado princípio, que a família não mais se restringe à matrimonial, havendo uma pluralidade de entidades familiar; a filiação não mais é sinônimo de vínculo biológico, tão somente, mas há a "posse do estado de filho", ${ }^{1}$ a multiparentalidade passa a ser uma realidade que enseja implicações práticas, inclusive de ordem patrimonial, que merecem estudo cauteloso.

Dessa forma, admitindo essa relação imbricada entre os princípios anteriormente pontuados e o instituto dos alimentos, passar-se-á à análise considerando como direito da personalidade, sem se olvidar, decerto, das controvérsias doutrinárias acerca, mas que não são objeto do presente estudo.

\subsection{Alimentos Como Direito da Personalidade}

É de conhecimento geral que o ser humano, desde sua mais elementar existência, necessitou sempre se alimentar para obter energia para exercer suas funções vitais.

No sistema jurídico pátrio, reconhecendo a importância dos alimentos, considerando-os numa acepção ampla que ultrapassa alimentação e inclui outros direitos como educação, vestuário e lazer, a Emenda Constitucional $n$ 은 10 , expressamente, incluiu-os como direito social.

A obrigação alimentar detém natureza superior, visto seu caráter de ordem pública, atuando em respeito à digna substância do alimentando, estando amparado no princípio da dignidade da pessoa humana e solidariedade familiar, princípios basilares da Lei Maior, bem como no Código Civil, como já ponderado anteriormente.

Consoante decorre do texto constitucional, o princípio da dignidade humana é a pedra de toque da fixação dos alimentos, numa conceituação plurívoca e para além de "alimentação", abrangendo todo e qualquer bem que promova e/ou mantenha aquele princípio (ex vi, artigo 227).

Esse dever constitucional (artigo 229) e legal é o reconhecimento jurídico do dever/obrigação mútua entre os membros da família, em que um tem para com o outro a obrigação de prestar os alimentos devidos.

Yussef Said Cahali, ao conceituar alimentos, destaca que

alimentos vêm a significar tudo o que é necessário para satisfazer aos reclamos da vida; são as prestações com as quais podem ser satisfeitas as necessidades vitais de quem não pode provê-las por si; mais amplamente, é a contribuição periódica assegurada a alguém, por um título de direito, para exigi-la de outrem, como necessário à sua manutenção $(2002$, p. 16).

Os alimentos no atual ordenamento legal (Código Civil) estão dispostos nos artigos 1.694 a 1.710, mencionando que os parentes, os cônjuges ou companheiros, têm o direito de pedir alimentos, quando forem necessários para sua subsistência. Esse direito também é recíproco entre os pais e filhos, estendendo-se a todos os seus ascendentes, e nessa falta, essa obrigação alcança os descendentes e após os irmãos, seja germanos, que são dos mesmos pais, ou unilaterais, de pais diferentes, conforme previsto no artigo 1.697.

Existem dois fatores que possuem fonte imediata na legislação vigente na obrigação de alimentar, um deles decorre do poder familiar, em que os pais têm a obrigação de sustentar seus filhos menores, e outro genérico, que transcorre da relação de parentesco seja biológico, seja afetivo, não havendo limites na linha reta e limitando-se na linha colateral ao segundo grau.

\footnotetext{
Para que haja a posse do estado de filho mister a presença concomitante de três elementos: nome, o trato e a fama, ou seja, na relação de aparência de filiação deve o filho e o pai e/ou mãe se tratarem como pais e filhos, serem assim reconhecidos socialmente e se nominarem como tal.
} 
Há que se registrar que a regra é a não solidariedade da obrigação alimentícia (artigo 1.698, Código Civil), ou seja, os parentes mais próximos excluem os mais remotos e só são chamados de modo subsidiário e para complementar os valores em caso de impossibilidade financeira daqueles (Súmula 596, STJ), à mingua de previsão legal e, logo, para que dada obrigação seja solidária mister que haja ou previsão legal ou ato de vontade (artigo 265, Código Civil), não havendo presunção.

Quanto à possibilidade de convocação de outros codevedores na ação de alimentos como modalidade autônoma de intervenção de terceiros, o artigo 1.698, Código Civil, previu, em caso de falta de condições financeiras do devedor em primeiro lugar, convocar-se as demais obrigadas na proporção de seus recursos. Ocorre que tal artigo não previu a modalidade de intervenção de terceiros ou de litisconsorte (não se sabe o que de fato é) que se deveria adotar, tampouco se só por parte do réu ou também do autor da ação. Seriam os alimentos, assim, solidários? Não. Tal previsão veio tão somente dar maior efetividade à satisfação alimentar; daí, por exemplo, se os avós maternos forem demandados para prestar alimentos aos netos, a título de complementação, não terão obrigação sozinhos, posto que não se trata de solidariedade (TJ/DF, Apelação Civil 188177, Rel. Des. Carmelita Brasil, DJ 14.04.04). Assim concorda Pontes de Miranda, por exemplo. Predomina o entendimento de que a obrigação não é solidária, há modalidade nova de intervenção de terceiros no artigo 1.698, Código Civil e não litisconsorte (se assim o fosse, absurdamente, só o autor da ação poderia o fazer).

O direito aos alimentos é considerado inderrogável e irrenunciável, como regra, uma vez que visa a proteger e preservar a vida, sendo considerado de ordem pública. Além disso, tem caráter personalíssimo, não transmitindo com o falecimento dos herdeiros do prestador, com exceção das dívidas vencidas até o falecimento do alimentante, em que fica a cargo do espólio. Assim, a obrigação dos alimentos não se transmite, mas apenas a dívida que já foi devidamente constituída, nos termos do artigo 1.707 Código Civil.

Quanto à fixação da pensão alimentícia, ela deve sempre observar o binômio necessidade e possibilidade, conforme preconiza o artigo 1.694 do Código Civil.

Assim, por serem os alimentos instrumento à promoção e/ou manutenção de vida digna da pessoa humana, há que concluir por sua natureza jurídica ${ }^{2}$ de direito da personalidade que já que visa a preservar a integridade psíquica e física de quem os recebe e é fixado de acordo com a possibilidade de quem os presta, os alimentos não admitem cessão (quer onerosa, quer gratuita), compensação, são impenhoráveis e têm preferência de pagamento no concurso de credores e não respeito à ordem dos precatórios (artigo 100, Constituição Federal).

Segundo Mário Delgado (2019, p. 6) os direitos da personalidade são “[...] direitos inerentes e essenciais à pessoa humana, decorrentes de sua exclusiva humanidade, e que protegem todas as suas projeções, nos planos físico ou espiritual, possibilitando, assim, ao ser humano, a defesa daquilo que lhe é próprio (honra, vida, liberdade, intimidade, privacidade, etc.)". Ou seja, são essenciais à dignidade e integridade do ser humano e são exigíveis dos particulares, enquanto que os fundamentais, do Estado, a despeito da forte tendência de se tratar os dois como sinônimos.

Nesse sentido, partindo-se do pressuposto de que o direito aos alimentos é pressuposto à vida digna e, como tal, é direito essencial e inderrogável, adentrar-se-á na análise de tal direito em cenário de multiparentalidade.

\section{MULTIPARENTALIDADE E ALIMENTOS NA VISÃO DO STF NO RECURSO EXTRAORDINÁRIO}

Antes de adentrarmos na conceituação do fenômeno da multiparentalidade, cabe tecer algumas breves ponderações quanto à filiação aqui considerada como fato jurídico compreendido em todas as relações $\mathrm{pai} / \mathrm{mãe}$ e filhos, independemente da origem, que enseja consectários legais e detém normatividade constitucional.

Ao destacar a função social da filiação, Cristiano Chaves de Farias assinala que

\footnotetext{
O tema não é pacifico, havendo quem defenda (Cristiano Chaves e Maria Berenice, por exemplo) deter natureza só extrapatrimonial (direito da personalidade) por decorrer do princípio da dignidade da pessoa humana; outros, só patrimonial. Prevalece, entretanto, a natureza mista dos alimentos (Orlando Gomes, Maria Helena Diniz, etc.), porque é direito patrimonial e finalidade pessoal.
} 
[...] com a normatividade isonômica constitucional, encartada na sua própria tábua axiológica (dignidade da pessoa humana, solidariedade social, igualdade e liberdade), infere-se, com tranqüilidade, que o direito filiatório infraconstitucional está submetido necessariamente a algumas características fundamentais: i) a filiação tem de servir à realização pessoal e ao desenvolvimento da pessoa humana (caráter instrumental do instituto, significando que a filiação serve para a afirmação da dignidade do homem); ii) despatrimonialização das relações paterno-filiais (ou seja, a transmissão de patrimônio é mero efeito da filiação, não marcando a sua essência); iii) a ruptura entre a proteção dos filhos e o tipo de relacionamento vivenciado pelos pais (2009, p. 474) (grifos nossos).

Vê-se que assim como a família é considerada "célula mater" da sociedade e verdadeiro microssistema social no qual seus membros se desenvolvem e se relacionam, tendo seu conceito evoluído (desde a visão patrimonialista e matriarcal do Código Civil de 1916 até a perspectiva constitucional, adotada pelo Código Civil atual, de admissão de várias formatações), a filiação sofreu modificações significativas: da visão discriminatória dos filhos havidos ou não do casamento e dos filhos naturais e adotivos para recorte de igualdade da filiação independentemente da origem e do reconhecimento da multiplicidades e cumulatividade de laços parentais (multiparentalidade).

Com acerto, assinalando que o rol disposto no artigo 226 da Constituição Federal é exemplificativo e que arranjos familiares calcados na afetividade, na pluralidade, na solidariedade, passaram a ser tutelados pelo Direito das Famílias, ratificando a ideia da interferência sociocultural naqueles, Christiano Cassettari afirma que "(...) a Constituição Federal ampliou o conceito de família, contemplando o princípio da igualdade da filiação, por meio da inserção de novos valores, calcando-se no princípio da afetividade e da dignidade da pessoa humana" (2017, p. 223).

Em outros termos: as alterações ocorridas no ambiente familiar e a "desbiologização" da maternidade e paternidade impuseram mudanças nos vínculos de parentesco e de filiação, rompendo com a arcaica definição de família como composta tão somente por pai, mãe e filhos biológicos.

Nesse contexto, tem-se fenômeno atual da multiparentalidade que, segundo Christiano Cassettari (2017, p. 219),

[...] é possível a coexistência da filiação socioafetiva com a biológica, onde uma pessoa poderia ter dois pais e/ou duas mães. Trata-se da multiparentalidade, que acreditamos ser possível e viável a sua existência, desde que fixadas certas premissas, já que entendemos que ela não pode, por exemplo, ser utilizada com finalidade patrimonial, pois a beleza do instituto está em dar a alguém a possibilidade de conviver com três ou mais pais ou mães ao longo da sua vida, recebendo deles todo carinho e afeto indispensável para o desenvolvimento saudável do ser humano.

A Constituição Federal criou cenário para que a afetividade pudesse ser considerada a constituição da entidade familiar, ampliando seu espectro, possibilitando, inclusive, a existência simultânea da filiação biológica com a socioafetiva, essa última independente da existência de registro civil, ratificando que a família detém uma função social: promover a felicidade dos seus entes.

Acerca do tema, lecionam Tybusch e Lemos;

Constata-se, portanto, que a multiparentalidade (dupla parentalidade; pluriparentalidade) se caracteriza pela admissão de o indivíduo ter dois vínculos de filiação distintos declarados em seu registro de nascimento, decorrentes da coexistência dos vínculos socioafetivo e biológico. Com efeito, afasta-se a regra de se fazer uma escolha entre a prevalência de quaisquer dos vínculos, como anteriormente foi necessário (2019, p. 312-313).

Nesse cenário, surge a multiparentalidade, antes já admitida pela doutrina mais vanguardista e com o julgado do STF, em que há o reconhecimento para todos os fins do pai socioafetivo sem afastar o biológico, como restará demonstrado a seguir.

O Supremo Tribunal Federal (STF), no julgamento do Recurso Extraordinário 898.060, em 22.9.2016, de relatoria do ministro Luiz Fux, por maioria, fixou tese com Repercussão Geral no sentido de que "a paternidade socioafetiva, declarada ou não em registro público, não impede o reconhecimento do vínculo de filiação concomitante baseado na origem biológica, com os efeitos jurídicos próprios" (Tese 622). Vejamos a ementa do julgado: 


\section{TíTULO}

Vínculo de filiação e reconhecimento de paternidade biológica

\section{ARTIGO}

A paternidade socioafetiva, declarada ou não em registro público, não impede o reconhecimento do vínculo de filiação concomitante baseado na origem biológica, com os efeitos jurídicos próprios. Com base nesse entendimento, o Plenário, por maioria, negou provimento a recurso extraordinário em que se discutia a prevalência da paternidade socioafetiva sobre a biológica. No caso, a autora, ora recorrida, é filha biológica do recorrente, conforme demonstrado por exames de DNA. Por ocasião do seu nascimento, a autora foi registrada como filha de pai afetivo, que cuidara dela, por mais de vinte anos, como se sua filha biológica fosse. $O$ Supremo Tribunal Federal afirmou que o sobreprincípio da dignidade humana, na sua dimensão de tutela da felicidade e realização pessoal dos indivíduos a partir de suas próprias configurações existenciais, impõe o reconhecimento, pelo ordenamento jurídico, de modelos familiares diversos da concepção tradicional. O espectro legal deve acolher tanto vínculos de filiação construídos pela relação afetiva entre os envolvidos quanto aqueles originados da ascendência biológica, por imposição do princípio da paternidade responsável, enunciado expressamente no art. 226, §7으, da CF. Dessa forma, atualmente não cabe decidir entre a filiação afetiva e a biológica quando o melhor interesse do descendente é o reconhecimento jurídico de ambos os vínculos. A omissão do legislador brasileiro quanto ao reconhecimento dos mais diversos arranjos familiares não pode servir de escusa para a negativa de proteção a situações de pluriparentalidade. Portanto, é importante reconhecer os vínculos parentais de origem afetiva e biológica. Todos os pais devem assumir os encargos decorrentes do poder familiar, e o filho deve poder desfrutar de direitos com relação a todos não só no âmbito do direito das famílias, mas também em sede sucessória. A Corte reputou ainda ser imperioso o reconhecimento da dupla parentalidade e manteve o acórdão de origem, que reconheceu os efeitos jurídicos de vínculo genético relativo ao nome, aos alimentos e à herança. Vencido o ministro Edson Fachin, que provia parcialmente o recurso, sob o argumento de que o parentesco socioafetivo não é prioritário ou subsidiário à paternidade biológica, tampouco um parentesco de segunda classe. Trata-se de fonte de paternidade, maternidade e filiação dotada da mesma dignidade jurídica da adoção constituída judicialmente, que afasta o parentesco jurídico daqueles que detêm apenas vínculo biológico. Dessa forma, segundo o ministro Edson Fachin, havendo vínculo socioafetivo com um pai e biológico com outro genitor, o vínculo socioafetivo se impõe juridicamente. 0 parentesco socioafetivo não é menos parentesco do que aquele estabelecido por adoção formal. Assim como o filho adotivo não pode constituir paternidade jurídica com outrem sob o fundamento biológico, também não pode o filho socioafetivo. Vencido, também, o ministro Teori Zavascki, que provia integralmente o recurso, sob o fundamento de que a paternidade biológica não gera, necessariamente, a relação de paternidade do ponto de vista jurídico, com as consequências daí decorrentes. O ministro rememorou, ainda, que havia, no caso, uma paternidade socioafetiva que persistiu e persiste. E, como não pode ser considerada menos importante do que qualquer outra forma de paternidade, ela deve ser preservada (BRASIL, STF. RE 898.060/SC, rel. min. Luiz Fux, julgamento em 21 e 22-9-2016).

Ao reconhecer a tese anterior, o STF não só reconheceu o instituto da paternidade socioafetiva a despeito de registro civil - o que ainda encontrava resistência doutrinária e jurisprudencial - como também sedimentou a situação de igualdade entre as formas de paternidade/maternidade, afastando discursos de que a socioafetiva seria de segunda categoria. Como se não bastassem tais efeitos, reconheceu a multiparentalidade, de modo que tanto os filhos, quanto os múltiplos pais/mães passam a deter direitos de família, como aos alimentos.

Há que se assinalar que, entrementes a decisão do STF seja emblemática e sua eficácia seja erga omnes ante o reconhecimento da repercussão geral, já havia vários julgados, invocando o princípio do melhor interesse da criança, ${ }^{3}$ admitindo a pluralidade de mães e de pais nos assentos de nascimento em razão da presença concomitante do pai/mãe afetivo com o biológico.

A doutrina também já reconhecia o dever do pai biológico, independentemente da existência de vínculo afetivo, de prestar alimentos ao filho, por força da responsabilidade parental e da natureza fundamental do instituto, como destacado por Rolf Madaleno ao tratar da paternidade alimentar, in verbis:

\footnotetext{
3 Em 2014, a juíza titular da 15a Vara de Família da Capital do Rio de Janeiro, Maria Aglae Vilardo, reconheceu o direito de três irmãos terem duas mães, a biológica e a socioafetiva, em seus registros de nascimento ante o falecimento da genitora e a assunção do papel materno da madrasta. Disponível em: http://www.ibdfam.org.br/noticias/5243/TJRJ+reconhece+multiparentalidade. Acesso em: 18 dez. 2019.
} 
Em tempos de verdade afetiva e de supremacia dos interesses da prole, que não pode ser discriminada e que tampouco admite romper o registro civil da sua filiação social já consolidada, não transparece nada contraditório estabelecer nos dias de hoje a paternidade meramente alimentar. Nela, o pai biológico pode ser convocado a prestar sustento integral ao seu filho de sangue, sem que a obrigação material importe em qualquer possibilidade de retorno à sua família natural, mas que apenas garanta o provincial efeito material de assegurar ao filho rejeitado vida digna, como nas gerações passadas, em que ele só podia pedir alimentos do seu pai que era casado e o rejeitara. A grande diferença e o maior avanço é que hoje ele tem um pai de afeto, de quem é filho do coração, mas nem por isso libera o seu procriador da responsabilidade de lhe dar o adequado sustento no lugar do amor (2006, p. 148).

O STF, na referida decisão, sedimentou o entendimento de que o conceito de família, no contexto de "constitucionalização do direito privado" ou "Direito Civil Constitucional" para os civilistas, teve seu espectro ampliado, inserindo "ingrediente" essencial, o afeto, na medida em que admitiu a concomitância da paternidade afetiva com a biológica, bem como as implicações práticas, como o dever de alimentar, ${ }^{4}$ decorrentes, incumbindo à doutrina o estudo pormenorizado de tais efeitos à luz da segurança jurídica.

\subsection{Os Alimentos na Multiparentalidade e STF}

A partir do entendimento do STF, sedimentado no Recurso Extraordinário 898.060, é indiscutível a possibilidade de se constar no mesmo assento de nascimento dois pais e/ou duas mães, no mínimo, com a filiação socioafetiva sendo reconhecida juridicamente com mesmo status da biológica.

Ademais, algumas indagações surgem quanto à operacionalização do dever de pagar alimentos nessas relações multiparentais: se o filho necessitar de alimentos, haverá possibilidade de cumulação de pensões? Em caso positivo, como incidirá o binômio necessidade-possibilidade; como se formaria o polo passivo da demanda: seriam todos coobrigados, haveria solidariedade ou se poderia eleger um a ser demandado, caso em que esse poderia chamar os demais à lide? Seria necessário prévio registro?

Outras dúvidas surgem: se os múltiplos pais necessitarem dos alimentos, o filho pode vir a ser demandado por ambos, passando a multiparentalidade a ser ônus e não o costumeiro "bônus" em que se justifica o reconhecimento no princípio do melhor interesse do petiz - os alimentos por ambos os pais proporcionarão formação educacional de melhor qualidade, por exemplo?

Pois bem. Ao cuidar da importância do registro civil da multiparentalidade, Christiano Cassettari (2017) defende sua necessidade, por questão de segurança jurídica, surtindo efeitos erga omnes, para que tanto pais quanto filhos possam, quando necessário, demandarem uns aos outros, o que, de fato, merece guarida, entrementes, por ser tal instituto posse de estado de filiação não há que se confundir meio de prova de constituição.

Depreende-se que incumbe sobretudo aos pais, entre outros direitos da personalidade, o de prestar alimentos que são imprescindíveis à promoção de cenário para vida minimamente digna dos filhos e vice-versa, a partir da necessidade do alimentando e da possibilidade do alimentante, sem, contudo, onerar em demasia o devedor. Daí, tanto os pais quanto os filhos podem pedir entre si os alimentos, inclusive na multiparentalidade, aplicando-se a mesma lógica na uniparentalidade, ou seja: há coobrigação dos pais/filhos de acordo com a capacidade financeira de cada um de prestar e a necessidade do credor, ${ }^{5}$ sendo divisível e não solidária, salvo quando se cuidar de idosos em que há a solidariedade (artigo 12, Estatuto do Idoso), podendo demandar de um ou de todos do polo passivo e ao demandado se utilizar do chamamento à lide em modalidade atípica, eis que não se amolda a nenhuma das hipóteses dispostas no Código de Processo Civil (artigos 119-138), embora a questão não seja pacífica.

\footnotetext{
${ }^{4}$ O Enunciado Programático no 6/2013, do IBDFAM, prevê que do reconhecimento jurídico da filiação socioafetiva decorrem todos os direitos e deveres inerentes à autoridade parental, motivo pelo qual é irrevogável.

5 Nesse sentido: TJRS, Apelação Cível, № 70078738317, Sétima Câmara Cível, Relator: Sandra Brisolara Medeiros, Julgado em: 26-9-2018.
} 
Registre-se, ainda, que, entrementes haja julgados tratando a obrigação concomitante dos avós maternos e paternos como litisconsórcio necessário, ${ }^{6}$ não se pode deixar de ter cautela com tais entendimentos, porque o binômio necessidade-possibilidade deve nortear todo e qualquer dever/obrigação de alimentar, de acordo com as peculiaridades do caso, bem como a lógica da subsidiariedade disposta no artigo 1.698 Código Civil. Assim, pode haver litisconsórcio passivo, mas não há obrigatoriedade. ${ }^{7}$

Quanto ao legitimado a requerer o chamamento ao codevedor, a Jornada de Direito Civil editou o Enunciado 523, in verbis: "O chamamento dos codevedores para integrar a lide, na forma do artigo 1.698 do Código Civil, pode ser requerido por qualquer das partes, bem como pelo Ministério Público, quando legitimado", o que atende ao melhor interesse do credor dos alimentos e ratifica o caráter personalíssimo do Direito.

Rodrigo da Cunha Pereira (2012, p. 246) destaca que "Independente da convivência ou relacionamento dos pais, a eles cabe a responsabilidade pela criação e educação dos filhos, pois é inconcebível a ideia de que o divórcio ou término da relação dos genitores acarrete o fim da convivência entre os filhos e seus pais.". No mesmo sentido, Gustavo Tepedino (1997, p. 48) assinala o papel da família no "[...] desenvolvimento da personalidade dos filhos", tendo-se, aí, a responsabilidade parental (artigo 226, §7으, CF/88 e artigo 100, IX, Estatuto da Criança e do Adolescente).

Ora, se os pais, em pleno exercício do planejamento familiar, decidem procriar, o mínimo que devem é cuidar, alimentar, educar sua prole, sob pena, inclusive, de incorrer na prática de ilícito penal (ex vi, artigos 244 a 247, Código Penal) e civil. Nesse tocante Cardin, Vieira e Brunini (2017, p. 52), ao tratarem do tema da responsabilidade civil por desobediência aos deveres inerentes ao poder familiar, eis que são direitos fundamentais à saúde, à educação, à vida, à filiação, todos integrantes da dignidade da pessoa humana, lecionam que

[...] aos pais cabe o dever jurídico de agir em relação aos filhos, isso é criar, educar, orientar, assistir moralmente da melhor forma possível, visando sempre o integral e melhor interesse do filho, a fim de que venha a desenvolver-se de forma saudável, de modo que sua omissão é, nos termos do art. 186 do Código Civil, considerada ato ilícito, visto que responsabiliza-se por omissão o agente que estiver em situação jurídica que obrigue a agir, a impedir um resultado.

Conquanto indubitável avanço ao Direito da Famílias o reconhecimento pelo STF da multiparentalidade, pondo uma pá de cal nesse talante, não se pode olvidar que as indagações antes expostas merecem estudo aprofundado e que se acompanhe o posicionamento do poder Judiciário nos casos práticos, posto que o instituto que se presta à concretização da dignificação das relações filiatórias não pode ser "vítima" de "aproveitadores" que abusem de direitos, como o aos alimentos, violando boa-fé objetiva, perseguindo o reconhecimento concomitante da paternidade biológica à socioafetiva para fins só mercenários.

Embora o julgado do STF tenha sido emblemático ao, em sede de repercussão geral, reconhecer como entidade familiar a multiparentalidade, em todo país, em controle difuso de constitucionalidade, diversos julgados reconheciam tal modalidade de família. No mesmo sentido, já se tinha textos normativos, tais como: a Lei da Guarda Compartilhada (Lei 13.058/2014), a Lei da Adoção (12.010/2009), a Lei da Alienação Parental (Lei 12.318/2010), Lei Clodovil (Lei 11.924/2009) e Código Civil (artigo1.593).

Nesse contexto, ao se admitir a simultaneidade de vínculo parental entre pais e filhos, estar-se-ia primando pelo melhor interesse desse grupo vulnerável, de modo que "(...) perpassa pelo respeito à dignidade da pessoa humana e pelo reconhecimento da socioafetividade como valor jurídico" (STEIN, 2008, p. 558). No mesmo sentido, Ricardo Calderón reconhece como consectário lógico da afetividade, entre outros, a possibilidade jurídica da multiparentalidade (CALDERÓN, 2016).

A despeito do caráter vanguardista do referido julgado, há que se assinalar que o ministro Luiz Edson Fachin, voto vencido, destacou inadmitir a multiparentalidade calcada tão somente no vínculo biológico quando já há parentesco socioafetivo com outrem, o que ratifica a importância do afeto à constituição da família (BRASIL, 2016).

\footnotetext{
REsp 958.513/SP, 4. a T., Rel. Min. Aldir Passarinho Junior, j. 22.2.2011, DJe 1.․3.2011.

REsp 964.866/SP, 4. a T., Rel. Min. João Otávio de Noronha, j. 1.․3.2011, DJe 11.3.2011.
} 
Enfim, a multiparentalidade deve ser reconhecida quando e tão somente há simultaneidade de relação de pais e filhos em que há concomitância do vínculo biológico com vínculo afetivo, possibilitando a igualdade de vínculos parentais, devendo-se, contudo, ter-se cautela para não se estender à mera relação entre enteados e madrastas/padrastos de per si, sob pena em se criar generalizações arriscadas e, no mínimo, injustas, ante os impactos jurídicos, como alimentos e direitos sucessórios.

Nos termos do voto do ministro relator Luiz Fux, "a compreensão jurídica cosmopolita das famílias exige a ampliação da tutela normativa a todas as formas pelas quais a parentalidade pode se manifestar, a saber: (i) pela presunção decorrente do casamento ou outras hipóteses legais, (ii) pela descendência biológica ou (iii) pela afetividade. A evolução científica responsável pela popularização do exame de DNA conduziu ao reforço de importância do critério biológico, tanto para fins de filiação quanto para concretizar o direito fundamental à busca da identidade genética, como natural emanação do direito de personalidade de um ser. A afetividade como critério, por sua vez, gozava de aplicação por doutrina e jurisprudência desde o Código Civil de 1916 para evitar situações de extrema injustiça, reconhecendo-se a posse do estado de filho, e consequentemente o vínculo parental, em favor daquele que utilizasse o nome da família (nominatio) fosse tratado como filho pelo pai (tractatio) e gozasse do reconhecimento da sua condição de descendente pela comunidade (reputatio)" (BRASIL, 2016).

Nessa perspectiva, do reconhecimento deste novel arranjo familiar decorrem, tal qual a família uniparental, direitos de ordem existencial e material, tais como o uso do sobrenome do padrasto/madrasta pelo enteado; o exercício da guarda e da convivência; o dever de assistência material mútua de acordo com o binômio necessidade-possibilidade.

Ao cuidar da obrigação de alimentar na multiparentalidade, Luiz Edson Fachin e Ana Carla Harmatiuk Matos destacam que "[...] esse importante dado da vida social deve transpor-se para o direito, de modo que se sustente a possibilidade de "dois pais" ou "duas mães" estarem obrigados a alimentos frente a uma mesma criança" (FACHIN; MATOS, 2009, p. 275).

Decerto que, embora em termos teóricos seja fácil reconhecer a multiparentalidade, a complexidade a sua aplicação à efetividade de alguns direitos não pode ser justificativa à proteção dos filhos dentro desse contexto, devendo-se buscar aprofundar o debate teórico e a discussão acadêmica ao clareamento da matéria.

Nessa senda, a atuação do Estado-Juiz, nos casos concretos de busca de reconhecimento da multiparentalidade e da aplicação dos alimentos dela decorrentes, deve ter como ponto de partida e de chagada concretização dos princípios da dignidade da pessoa humana, da solidariedade e da responsabilidade parental.

\section{CONSIDERAÇÕES FINAIS}

Com a Constituição Federal a dignidade da pessoa humana assume papel de fundamento de validade de todo ordenamento jurídico, irradiando seus efeitos tanto nas relações horizontais como verticais, exigindo-se que se observe os direitos fundamentais e da personalidade em jogo.

O Direito Civil contemporâneo também sofreu significativos impactos ante a força normativa da Constituição, com verdadeira mudança paradigmática, rompendo com o modelo patrimonialista do Código Civil de 1916, em que o matrimônio era a entidade familiar de "primeira categoria" e as demais "vítimas" de preconceito, tal qual ocorria com a filiação, tratando de modo discriminatório os filhos havidos ou não do casamento.

Nessa perspectiva, o presente estudo buscou demonstrar como, sobretudo nas relações familiares, princípios como da dignidade da pessoa humana, da solidariedade e da afetividade passaram a influenciar os julgadores na solução de casos concretos nos quais a regra jurídica se revela insuficiente a responder, dando ênfase nesse último fundamento axiológico e sua aplicabilidade prática no instituto da filiação, analisando a paternidade/maternidade afetiva em que o afeto se revela como elemento essencial.

A partir do julgado analisado no artigo em comento, pôde-se observar a possibilidade da multiparentalidade configurar entidade familiar, logo, digna de tutela jurídica do Direito das Famílias, embora quanto aos efeitos patrimoniais dessa relação familiar, como os alimentos - que traz em seu bojo caráter essencial-, mister se aprofundar o debate. 
Daí, a partir de sucinto retrospecto histórico do conceito de família até desembocar na variabilidade de espécie que marca a contemporaneidade do tema, incluindo a pluriparentalidade, o que encontra respaldo no artigo 226, caput, do texto constitucional - é clausula geral de inclusão.

Ponderou-se como o princípio da dignidade da pessoa humana exerce papel de relevo não só à concretização da força normativa da Constituição, como à unidade do sistema jurídico, além do da responsabilidade parental do qual decorre o dever de guarda - vivência, cuidado e sustento em relação aos filhos sanguíneos e afetivos, destacando o debate quanto à natureza jurídica da afetividade - se princípio ou valor jurídico. Também tratou-se do princípio-ancora do Estatuto Menorista, o do melhor interesse da criança e do adolescente, segundo o qual ao Estado, à sociedade e à família incumbe o dever de voltar o olhar a esse grupo vulnerável, priorizando o atendimento e as políticas públicas, reconhecendo-o como sujeito de direitos.

Nesse contexto de influência múltipla de princípios, adentrou-se na discussão quanto aos alimentos, conceituando como o mínimo necessário à vida digna, mantendo o status quo ante - quando se cuidar de fiIhos - ou resguardando a sobrevivência - se for em relação a outros parentes - reconhecendo, a despeito da controvérsia doutrinária, sua natureza de direito da personalidade por deter relação direta com elementos essenciais à concretização de vida digna ao ser humano e que exige não só do Estado, como dos particulares - numa relação horizontal - respeito. Em seguida, apresentou-se características dos alimentos, legitimados e aspectos processuais relevantes, passando ao estudo do julgado Recurso Extraordinário 898.060/SC no Supremo Tribunal Federal no qual se reconheceu a multiparentalidade e o tratamento da verba alimentar nesse cenário, buscando responder à seguinte perquirição: Qual a efetividade dos alimentos quando se está diante da existência simultânea de relação de parentesco entre pais e/ou mães e filhos - multiparentalidade? Quais os limites, alcance e efeitos práticos ao se admitir tal possibilidade?

Ora, ante a função social da família, ponderou-se que a afetividade permeando a relação pai/mãe e filho otimiza o desenvolvimento saudável dos filhos e, logo, de adulto consciente de seus direitos e deveres, sua proteção ultrapassa o viés patrimonialista, incluindo a dignidade dos seus componentes como finalidade precípua, havendo verdadeira personificação das proteções civis.

Tomando como base não só visão doutrinária abalizada, mas sobretudo a decisão do Supremo Tribunal Federal, exarada nos autos do Recurso Extraordinário no 898.060, em 22.9.2016, de relatoria do ministro Luiz Fux, em que, por maioria, se reconheceu a existência concomitante da filiação socioafetiva com a biológica, ou seja, a multiparentalidade, procedeu-se à pesquisa em comento, calcada em método dedutivo, exploratório e "análise de decisões".

Destacou-se que, ao firmar a tese 622 , segundo a qual "a paternidade socioafetiva, declarada ou não em registro público, não impede o reconhecimento do vínculo de filiação concomitante baseado na origem biológica, com os efeitos jurídicos próprios", a Corte Constitucional não só reconheceu o instituto da paternidade socioafetiva a despeito de registro civil - o que ainda encontrava resistência doutrinária e jurisprudencial - como também sedimentou a situação de igualdade entre as formas de paternidade/maternidade, afastando discursos de que a socioafetiva seria de segunda categoria, além de direitos próprios do Direitos das Famílias, dando base a que direitos decorrentes dessa relação, como aos alimentos e à herança, possam ser reconhecidos.

Decerto que, por serem os alimentos instrumento para a promoção e/ou manutenção de vida digna da pessoa humana, seu caráter fundamental é óbvio, de modo que deve ser fixado em compasso com o binômio necessidade-possibilidade, preservando a integridade do credor e do devedor, não sendo, em regra, obrigação solidária, mas divisível, razão pela qual, embora não seja a jurisprudência pacífica, assinalou-se que, tal qual ocorre na uniparentalidade, na multiparentalidade os codevedores não são solidários, devendo cada um prestar os alimentos de acordo com o binômio, podendo, chamar à lide os demais - ponderou-se não se entender por litisconsórcio necessário, mas por chamamento à lide atípico.

Ora, é de conhecimento geral que o dever de alimentar dos pais em relação aos filhos é compartilhado de modo a não onerar demais um em detrimento do outro, considerando-se a capacidade econômica do alimentante. Cuida-se de obrigação concorrente de ambos ou de todos os pais, de modo que a mesma lógica deve ser aplicada na pluralidade parental, não se podendo, contudo, olvidar da proibição do enriquecimento ilícito. 
Conquanto se tenha observado que a jurisprudência pátria tenha reconhecido a parentalidade socioafetiva, não se depreende dos julgados a análise das consequências de tal reconhecimento, daí a relevância do estudo.

Nesse diapasão, observou-se que o Direito Civil contemporâneo, ante a influência do texto constitucional, incorporou valores, rompendo com a visão patrimonialista, admitindo a pluralidade de entidades familiares e, logo, a multiparentalidade que representa uma modalidade de família pós-moderna, calcada na afetividade, na solidariedade recíproca dos seus membros de seus membros, onde direitos da personalidade, como aos alimentos, precisam ser reconhecidos.

O estudo da multiparentalidade, considerado como a existência simultânea de relações de parentesco entre pelo menos dois pais ou mães e seus filhos revela-se imprescindível à compreensão atual da família contemporânea, em que a afetividade e o melhor interesse do petiz devem nortear o Estado. Considerando que o reconhecimento pelo STF dessa nova formatação de entidade familiar tenha seu relevo, há que assinalar a necessidade de aprofundar o debate, eis que não houve, no referido julgado, a análise dos limites, alcance e, sobretudo, os impactos jurídicos noutros institutos. Daí a pretensão do presente estudo.

\section{REFERÊNCIAS}

BRASIL. Supremo Tribunal Federal (STF). Recurso Extraordinário 898.060/SC. Rel. ministro Luiz Fux. Data do julgamento: 21 e 22-9-2016. 2016. Disponível em: http://redir.stf.jus.br/paginadorpub/paginador.jsp?docTP=TP\&doclD=13431919. Acesso em: 12 abr. 2019.

CAHALI, Yussef Said. Dos alimentos. 4. ed. São Paulo: Revista dos Tribunais, 2002.

CALDERÓN, Ricardo Lucas. Princípio da afetividade no Direito de Família. Rio de Janeiro: Renovar, 2013.

CALDERÓN, Ricardo Lucas. Reflexos da decisão do STF que acolheu a socioafetividade e a multiparentalidade. 2016. Disponível em: http://www.conjur.com.br/2016-set-25/processo-familiar-reflexos-decisao-stf-acolher-socioafetividademultiparentalidade. Acesso em: 10 fev. 2020.

CALDERÓN-VALENCIA, Felipe; ESCOBAR-SIERRA, Manuela. L'articulation de la juridiction spéciale pour la paix avec la justice ordinaire en matière d'extradition: les enjeux politiques du cas Jesus Santrich dans le contexte du post-conflit Colombien. Revista Direitos Sociais e Políticas Públicas - Unifafibe, v. 7, n. 1, 2019.

CARDIN, Valéria Silva; VIEIRA, Tereza Rodrigues; BRUNINI, Bárbara Cissettin Costa. Famílias, Psicologia e Direito. Brasília: Editora Zakarewicz, 2017.

CASSETTARI, Cristiano. Multiparentalidade e parentalidade socioafetiva: efeitos jurídicos. 3. ed. São Paulo: Atlas, 2017.

CIARLINI, Léa Martins Sales; CIARLINI, Alvaro Luis de Araujo. A estrutura das políticas públicas e os paradoxos da intervenção judicial por meio da ação civil pública: uma análise a partir dos cinco estágios do ciclo político-administrativo de Michael Howlett, Ramesh e Perl. Revista Direitos Sociais e Políticas Públicas - Unifafibe, v. 7, n. 1, 2019.

DELGADO, Mário Luiz. Direitos da personalidade nas relações de família. Disponível em: http://www.ibdfam.org.br/_img/congressos/anais/34.pdf. Acesso em: 1ㅇdez. 2019.

FACHIN, Luiz Edson. Estatuto jurídico do patrimônio mínimo. Rio de Janeiro: Renovar, 2001.

FACHIN, Luiz Edson; MATOS, Ana Carla Harmatiuk. Subsídios solidários: filiação socioafetiva e alimentos. In: CORTIANO, Junior, Eroulths; MEIRELLES, Jussara Maria Leal de; FACHIN, Luiz Edson; NALIN, Paulo (coord.). Apontamentos críticos para o direito civil brasileiro contemporâneo. Curitiba: Juruá, 2009.

FACHIN, Luiz Edson. Princípio da pluralidade familiar. In: TORRES, Ricardo Lobo; KATAOKA, Eduardo Takemi; GALDINO, Flavio (org.). Dicionário de princípio jurídicos. Rio de Janeiro: Elsevier, 2011.

FACHIN, Zulmar. Curso de Direito Constitucional. 8. ed. São Paulo: Editora Verbatim, 2019.

FARIAS, Cristiano Chaves de. Manual de Direito Civil. Salvador: JusPodivm, 2017. Volume único.

FLORIANI, Lara Bonemer Rocha; SANTOS, Luccas Farias. A hierarquia dos tratados internacionais e seus reflexos jurídicos e extrajurídicos. Revista Direitos Sociais e Políticas Públicas - Unifafibe, v. 7, n. 1, 2019.

GROENINGA, Giselle Câmara. Direito Civil. Vol. 7. In: HIRONAKA, Giselda M. F Novaes; BARBOSA, Aguida Arruda; VIEIRA, Cláudia Stein (coord.). Direito de Família. São Paulo: RT, 2008. p. 47-52.

HESSE, Konrad. A força normativa da Constituição. Porto Alegre: Sergio Antonio Fabris Editor, 1991.

LASCANO, Alfonso Jaime Martinez. Inconvencionalidad del amparo mexicano por la eficacia en la protección judicial de derechos humanos. Revista Direitos Sociais e Políticas Públicas - Unifafibe, v. 7, n. 2, 2019.

LÔBO, Paulo Luiz Netto. Direito civil: famílias. 3. ed. São Paulo: Saraiva, 2010. p. 61. 
LÔBO, Paulo Luiz Netto. Princípio da solidariedade familiar. Disponível em: http://www.ibdfam.org.br/_img/congressos/ anais/78.pdf. Acesso em: 29 set. 2019.

LÔBO, Paulo Luiz Netto. Entidades familiares constitucionalizadas: para além do numerus clausus. CONGRESSO BRASILEIRO DE DIREITO DE FAMÍLIA: FAMÍLIA E CIDADANIA, 3., 2002. Belo Horizonte. Anais [...]. Belo Horizonte: IBBDFAM/OAB-MG, 2002.

MABTUM, Matheus Massaro; GERRA FILHO, Willis Santiago. A importância do tempo e sentido para a teoria dos sistemas de Niklas Luhmann. Revista Direitos Sociais e Políticas Públicas - Unifafibe, v. 6, n. 2, 2018.

MADALENO, Rolf. Paternidade Alimentar. In: Revista Brasileira de Direito de Família, n. 37, p.148, 2006.

MATOS, Ana Carla Harmatiuk. A família recomposta: em busca de seu pleno reconhecimento jurídico. In: MATOS, Ana Carla Harmatiuk; MENEZES, Joyceane Bezerra (org.). Direito das famílias por juristas brasileiras. São Paulo: Editora Saraiva, 2013. p. 319-335.

MORAES, Maria Celina Bodin. Ampliando os direitos da personalidade. In.: VIEIRA, José Ribas (org.). 20 anos da Constituição Cidadã de 1988: efetivação ou impasse institucional. Rio de Janeiro: Forense, 2008. Disponível em: https://www.academia. edu/9689598/Ampliando_os_direitos_da_personalidade. Acesso em: 29 mar. 2019.

MORAES, Maria Celina Bodin de. A nova família, de novo: estruturas e função das famílias contemporâneas. Revista Pensar, Fortaleza, v. 18, n. 2, 2013. Disponível em: http://ojs.unifor.br/index.php/rpen/article/view/2705. Acesso em: 9 fev. 2020.

PEREIRA, Rodrigo da Cunha. Princípios fundamentais norteadores do direito de família. 2. ed. São Paulo: Saraiva, 2012.

PIANOVSKI RUZYK, Carlos Eduardo. Famílias simultâneas: da unidade codificada à pluralidade constitucional. Rio de Janeiro: Renovar, 2005.

ROSSIGNOLI, Marisa; SOUZA, Francielle Calegari de. O princípio constitucional da livre concorrência frente a política do desenvolvimento sustentável. Revista Direitos Sociais e Políticas Públicas - Unifafibe, v. 7, n. 1, 2019.

SARLET, Ingo Wolfgang. Dignidade da Pessoa Humana e Direitos Fundamentais na Constituição Federal de 1988. Porto Alegre: Livraria do Advogado, 2001.

SOARES, Marcelo Negri; KAUFFMAN, Marcos Eduardo; MARTIN, Raphael Farias. Economy law and economic analysis of law and the impacto on intellectual property in the common law system. Revista Direitos Sociais e Políticas Públicas - Unifafibe, v. 7, n. 2, 2019.

STEIN, Thais Silveira. O estabelecimento da paternidade e a dignidade da pessoa humana nas relações familiares. In: PEREIRA, Tânia da Silva; PEREIRA, Rodrigo da Cunha (coord.). A ética da convivência familiar. Rio de Janeiro: Forense, 2008.

STURZA, Janaína Machado; RODRIGUES, Bruna dos Passos. Diálogos entre políticas públicas e direito à saúde: as audiências públicas enquanto instrumento de participação popular sob a perspectiva da teoria da ação comunicativa de Habermas. Revista Direitos Sociais e Políticas Públicas - Unifafibe, v. 7, n. 2, 2019.

TARTUCE, Flávio. Manual de Direito Civil: volume único. Rio de Janeiro: Forense; São Paulo: Método, 2011.

TEPEDINO, Gustavo. A tutela da personalidade no ordenamento civil-constitucional brasileiro. In: TEPEDINO, Gustavo. Temas de Direito Civil. 3. ed. rev. e atual. Rio de Janeiro: Renovar, 2004a.

TEPEDINO, Gustavo. Temas de Direito Civil. 3. ed. rev. e atual. Rio de Janeiro: Renovar, $2004 \mathrm{~b}$.

TEPEDINO, Gustavo. A disciplina civil-constitucional das relações familiares. A nova família: problemas e perspectivas. Rio de Janeiro: Renovar, 1997.

TYBUSCH, Francielle Benini Agne; LEMOS, Luan Martins. A entidade familiar contemporânea e o afeto como gerador de vínculo de parentalidade: a solidificação da multiparentalidade por meio do registro civil. Revista Jurídica Cesumar - Mestrado, v. 19, n. 1, p. 301-329, jan./abr. 2019. - e- ISSN 2176-9184.

ZEIFERT, Anna Paula Bagetti. Pensar as políticas públicas a partir do enfoque das capacidades: justiça social e respeito aos direitos humanos. Revista Direitos Sociais e Políticas Públicas - Unifafibe, v. 7, n. 1, 2019. 